\title{
Investigate the Effect of Cutting Parameters on Surface Roughness When Milling X12m Steel
}

\author{
Do Thi Kim Lien ${ }^{1,}$, Nguyen Dinh Man², Phùng Trân Đính ${ }^{3}$ \\ ${ }^{1}$ Faculty of Mechanical Engineering, Viet Hung Industrial University, Vietnam \\ ${ }^{2}$ Faculty of Mechanical Engineering, Thainguyen University of Technology, Vietnam \\ ${ }^{3}$ Faculty of Mechanical Engineering, Viet Hung Industrial University, Vietnam
}

\begin{abstract}
Article Info

Volume 8 Issue 2

Page Number: 258-263

Publication Issue :

March-April-2021

\section{Article History}

Accepted : 05 April 2021

Published : 11 April 2021

In this paper, an experimental study on the effect of cutting parameters on surface roughness was conducted when milling X12M steel. The cutting tool used in this study is a face milling cutter. The material that is used to make the insert is the hard alloy T15K6. The cutting parameters covered in this study include the cutting speed, the feed rate and depth of cut. The experiments are performed in the form of a rotating center composite design. The analysis shows that for both Ra and Rz: (1) the feed rate has the greatest influence on the surface roughness while the depth of cut, the cutting speed has a negligible effect on the surface roughness. (2) only the interaction between the feed rate and the depth of the cut has a significant effect on both $\mathrm{Ra}$ and $\mathrm{Rz}$ while the interaction between the cutting speed and the feed rate, the interaction between the cutting speed and the depth of cut have a negligible effect on surface roughness. A regression equation showing the relationship between Ra, $\mathrm{Rz}$, and cutting parameters has also been built in this study.
\end{abstract}

Keywords : X12M steel, surface milling, face milling cutter, surface roughness

\section{INTRODUCTION}

The milling method is increasingly used to process products in the mechanical industry. In terms of machining productivity, milling is one of the methods for the highest productivity. In addition, with the development of milling machines, milling cutters in recent years, the quality of machining surfaces during milling has also been significantly improved. Therefore, in some cases, milling is also chosen as the final machining method.
In order to process a part surface with a small roughness, one of the most common methods in machine fabrication is to select and control the values of the cutting parameters. To do this, first of all, it is necessary to determine the extent and the rules of influence of cutting parameters on surface roughness. Then, there will be the basis to select and control the value of parameters of cutting parameters. This work has been performed by many authors while studying milling of different materials. 
D. D. Trung researched when milling AISI 1045 steel [1]. Hasan Gökkaya [2] studied the AA2014 alloy milling. Muhammmad Yasir et al. [3] studied the AISI 316L SS steel milling. Luis Wilfredo Hernández-González et al. [4] conducted steel milling AISI 304. Huu-That Nguyen et al. [5] performed steel milling SKD61. Pathak et al. [6] studied the milling process of two alloys, Al-1Fe$1 \mathrm{~V}-1 \mathrm{Si}$ and Al-2Fe-1V-1Si. Erol Kilickap et al. [7] experimented to investigate the effect of cutting parameters on surface roughness when milling $\mathrm{Ti}$ 6242S alloy. Okokpujie Imhade et al. [8] experimented with milling 6061 aluminum alloy under the condition of Minimum Quantity Lubrication (MQL). Nguyen Thanh Binh et al. [9] studied the steel milling SKD61. Pham Thi Hoa et al. [10] studied the effect of cutting parameters on surface roughness when milling A6061 aluminum alloy, etc. In this paper, an experimental study will be conducted to determine the influence of cutting parameters on surface roughness when milling X12M steel.

\section{MILLING EXPERIMENT}

\subsection{Experimental system}

The experiments were performed on the DUSONG DNME 448. Two-insert face milling cutters were used in this study.
The experimental material is $\mathrm{X} 12 \mathrm{M}$ steel which is popular in the machine-building industry, has good machinability, is often used to manufacture parts subjected to static loads, sometimes is also used to manufacture parts that withstand impact in the working process, parts with wear-resistant surfaces, such as axes and gears.

Surface roughness was measured with the SJ201 roughness tester (Mitutoyo - Japan). For each experimental sample, at least 5 measurements were carried out. The roughness value at each experiment ( $\mathrm{Ra}$ and $\mathrm{Rz}$ ) is the average value of successive measurements.

\subsection{Design the experiment}

The center composite design matrix was used to design the experiments in this study with 3 parameters on cutting parameters including cutting speed, the feed rate, and depth of cut. The central composite design is formed by a design combination of $2 \mathrm{k}$ ( $\mathrm{k}$ is the number of input parameters) $2 \mathrm{k}$ along axis test points and a number of experimental points at the center $[11,12]$. The values of the cutting parameters at the coding levels are shown in Table 1. Experimental matrixes are presented in Table 2.

Table 1. Value of parameters at the levels

\begin{tabular}{|c|c|c|c|c|c|c|}
\hline \multirow{2}{*}{ Input parameters } & \multirow{2}{*}{ symbol } & \multicolumn{5}{|c|}{ Values at levels } \\
\cline { 3 - 8 } & & -1.68 & -1 & 0 & 1 & -1.68 \\
\hline Cutting speed (m/min) & $\mathrm{v}$ & 120 & 146.35 & 185 & 223.65 & 250 \\
\hline Feed rate (mm/tooth) & $\mathrm{f}$ & 0.08 & 0.1 & 0.13 & 0.16 & 0.18 \\
\hline Depth of cut (mm) & $\mathrm{t}$ & 0.2 & 0.281 & 0.4 & 0.519 & 0.6 \\
\hline
\end{tabular}

Table 2. Matrix of experiments and results

\begin{tabular}{|c|c|c|c|c|c|c|c|c|}
\hline \multirow{2}{*}{ No. } & \multicolumn{3}{|c|}{ Code value } & \multicolumn{3}{|l|}{ Real value } & \multirow{2}{*}{$\mathrm{Ra}(\mu \mathrm{m})$} & \multirow{2}{*}{$\begin{array}{l}\mathrm{Rz} \\
(\mu \mathrm{m})\end{array}$} \\
\hline & $\mathrm{v}$ & $\mathrm{f}$ & $\mathrm{t}$ & $\mathrm{v}(\mathrm{m} / \mathrm{min})$ & $\mathrm{f}(\mathrm{mm} /$ tooth $)$ & $\mathrm{t}(\mathrm{mm})$ & & \\
\hline 1 & 0 & 0 & -1.68 & 185 & 0.13 & 0.2 & 0.99 & 2.98 \\
\hline 2 & 0 & 0 & 1.68 & 185 & 0.13 & 0.6 & 0.13 & 0.77 \\
\hline 3 & -1 & 1 & -1 & 146.35 & 0.16 & 0.281 & 0.78 & 4.16 \\
\hline 4 & 1 & 1 & -1 & 223.65 & 0.16 & 0.281 & 0.86 & 4.34 \\
\hline 5 & 0 & 0 & 0 & 185 & 0.13 & 0.4 & 0.57 & 2.09 \\
\hline
\end{tabular}




\begin{tabular}{|c|c|c|c|c|c|c|c|c|}
\hline 6 & 1 & 1 & 1 & 223.65 & 0.16 & 0.519 & 0.15 & 0.88 \\
\hline 7 & -1.68 & 0 & 0 & 120 & 0.13 & 0.4 & 0.16 & 0.98 \\
\hline 8 & 1.68 & 0 & 0 & 250 & 0.13 & 0.4 & 0.26 & 1.71 \\
\hline 9 & 0 & 1.68 & 0 & 185 & 0.18 & 0.4 & 1.48 & 6.83 \\
\hline 10 & 0 & 0 & 0 & 185 & 0.13 & 0.4 & 0.29 & 1.69 \\
\hline 11 & 0 & 0 & 0 & 185 & 0.13 & 0.4 & 0.37 & 1.55 \\
\hline 12 & 0 & 0 & 0 & 185 & 0.13 & 0.4 & 0.34 & 1.69 \\
\hline 13 & 0 & 0 & 0 & 185 & 0.13 & 0.4 & 0.41 & 2.19 \\
\hline 14 & -1 & -1 & 1 & 146.35 & 0.10 & 0.519 & 0.65 & 3.51 \\
\hline 15 & 1 & -1 & 1 & 223.65 & 0.10 & 0.519 & 0.40 & 2.44 \\
\hline 16 & -1 & 1 & 1 & 146.35 & 0.16 & 0.519 & 0.27 & 1.75 \\
\hline 17 & -1 & -1 & -1 & 146.35 & 0.10 & 0.281 & 0.26 & 1.45 \\
\hline 18 & 1 & -1 & -1 & 223.65 & 0.10 & 0.281 & 0.47 & 2.35 \\
\hline 19 & 0 & 0 & 0 & 185 & 0.13 & 0.4 & 0.26 & 1.30 \\
\hline 20 & 0 & -1.68 & 0 & 185 & 0.08 & 0.4 & 0.18 & 1.49 \\
\hline
\end{tabular}

\section{ANALYSIS OF RESULTS AND DISCUSSION}

\subsection{The influence of parameters on Ra}

Surface roughness values at each experiment were given in Table 2. Analyze the experimental results in Table 2. The ANOVA analysis results for Ra are presented respectively in Table 3 . The influence level of the Cutting parameters on Ra is shown in Fig 1. Interaction between parameters on a Fig 2

Table 3. Results of ANOVA analysis for Ra

\begin{tabular}{|c|c|c|c|c|}
\hline & $\mathrm{df}$ & SS & MS & $\mathrm{F}$ \\
\hline Regression & 9 & 1.6462 & 0.1829 & 3.2379 \\
\hline Residual & 10 & 0.5649 & 0.0565 & \\
\hline \multirow[t]{2}{*}{ Total } & 19 & 2.2111 & & \\
\hline & Coefficients & Standard Error & t Stat & P-value \\
\hline Intercept & 0.3753 & 0.0969 & 3.8715 & 0.0031 \\
\hline $\mathrm{v}$ & 0.0055 & 0.0643 & 0.0858 & 0.9333 \\
\hline $\mathrm{f}$ & 0.1802 & 0.0643 & 2.8013 & 0.0188 \\
\hline $\mathrm{t}$ & -0.1725 & 0.0643 & -2.6810 & 0.0231 \\
\hline $\mathrm{v}^{*} \mathrm{v}$ & -0.0711 & 0.0627 & -1.1346 & 0.2830 \\
\hline$f * f$ & 0.1475 & 0.0627 & 2.3523 & 0.0405 \\
\hline$t * t$ & 0.0524 & 0.0627 & 0.8352 & 0.4231 \\
\hline $\mathrm{v} * \mathrm{f}$ & -0.0012 & 0.0840 & -0.0138 & 0.9893 \\
\hline $\mathrm{v} * \mathrm{t}$ & -0.0820 & 0.0840 & -0.9762 & 0.3520 \\
\hline $\mathrm{f} * \mathrm{t}$ & -0.1915 & 0.0840 & -2.2786 & 0.0459 \\
\hline
\end{tabular}




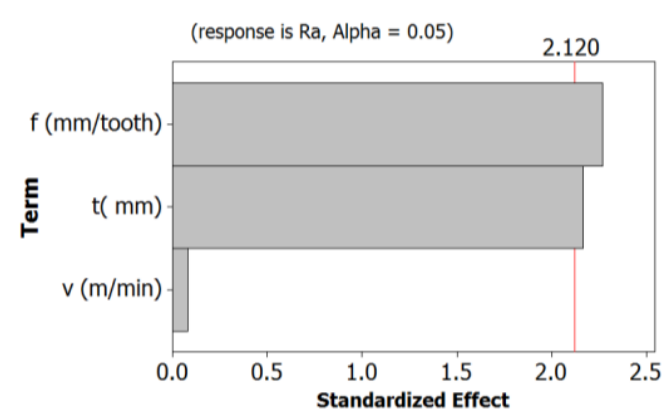

Fig. 1. Main effect on Ra

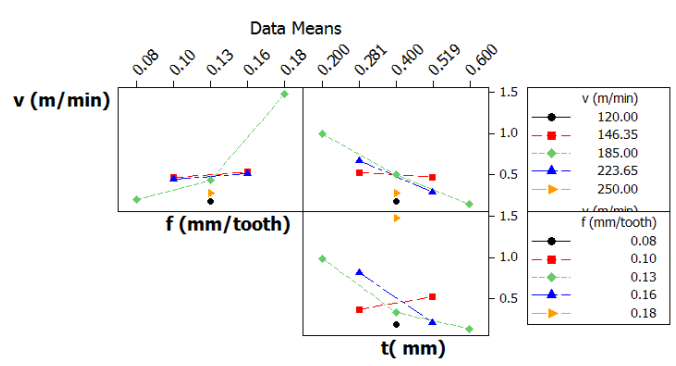

Fig. 2 Interaction influence between parameters on

$\mathrm{Ra}$

Observing table 3 shows:

The feed rate has the greatest influence on the roughness $\mathrm{Ra}$ while the influence of the depth of the cutting, the cutting speed having a negligible effect on the surface roughness. This problem will also be more obvious when observing figure 1 . As the feed rate increases, the surface roughness goes up. The surface roughness will decrease if the depth of cut increases.

Only the interaction between the feed rate and the depth of cut has a significant effect on Ra. The interaction between the cutting speed with the feed rate and between the cutting speed with the depth of cutting has a negligible effect on $\mathrm{Ra}$. The diagrams in Figure 2 also partly support this observation.

\subsection{The influence of the parameters on $\mathrm{Rz}$} ANOVA analysis results for $\mathrm{Rz}$ are presented respectively in Table 4 . The impact level of cutting parameters on $\mathrm{Rz}$ is presented in Figure 3. The interaction effect between parameters on $\mathrm{Rz}$ is presented in figure 4

Table 4. Results of ANOVA analysis for Rz

\begin{tabular}{|l|r|r|r|r|r|}
\hline & \multicolumn{1}{|c|}{$d f$} & \multicolumn{1}{c|}{$S S$} & $M S$ & \multicolumn{1}{c|}{$F$} & Significance $F$ \\
\hline Regression & 9 & 32.8112 & 3.6457 & 4.6751 & 0.0122 \\
\hline Residual & 10 & 7.7981 & 0.7798 & & \\
\hline Total & 19 & 40.6094 & & & \\
\hline & Coefficients & $\begin{array}{c}\text { Standard } \\
\text { Error }\end{array}$ & \multicolumn{1}{|c|}{ Stat } & P-value & Lower $95 \%$ \\
\hline Intercept & 1.7501 & 0.3601 & 4.8596 & 0.0007 & 0.9477 \\
\hline $\mathrm{v}$ & 0.0266 & 0.2391 & 0.1111 & 0.9138 & -0.5061 \\
\hline $\mathrm{f}$ & 0.7595 & 0.2391 & 3.1772 & 0.0099 & 0.2269 \\
\hline $\mathrm{t}$ & -0.5449 & 0.2391 & -2.2793 & 0.0458 & -1.0775 \\
\hline $\mathrm{v} * \mathrm{v}$ & -0.1228 & 0.2330 & -0.5269 & 0.6097 & -0.6419 \\
\hline $\mathrm{f} * \mathrm{f}$ & 0.8763 & 0.2330 & 3.7611 & 0.0037 & 0.3572 \\
\hline $\mathrm{t} * \mathrm{t}$ & 0.0663 & 0.2330 & 0.2848 & 0.7816 & -0.4528 \\
\hline $\mathrm{v} * \mathrm{f}$ & -0.0646 & 0.3122 & -0.2068 & 0.8403 & -0.7602 \\
\hline $\mathrm{v} * \mathrm{t}$ & -0.3773 & 0.3122 & -1.2085 & 0.2547 & -1.0730 \\
\hline $\mathrm{f} * \mathrm{t}$ & -1.0026 & 0.3122 & -3.2114 & 0.0093 & -1.6983 \\
\hline
\end{tabular}

Observing table 4 shows:

Cutting speed has a negligible influence on Rz. The depth of cut and the Feed rate both have a significant influence on the Rz. In which, the influence of the Feed rate on $\mathrm{Rz}$ is greater than the influence of the cutting depth. The value of surface roughness will decrease if the value of the Feed rate decreases and 
the value of the cutting depth increases. Observing figure 3 will also find this comment completely appropriate.

- The interaction between the cutting speed with the Feed rate, and the interaction between the cutting speed and the depth of cutting have a negligible effect on Rz. Meanwhile, the interaction between the Feed rate and the depth of cut has a significant effect on $\mathrm{Rz}$. The graph of the interaction effect between cutting parameters to $\mathrm{Rz}$ presented in Figure 4 will also make this statement clearer.

\section{CONCLUSION}

In this study, the level and rule of the influence of cutting speed, Feed rate, and cutting depth on surface roughness ( $\mathrm{Ra}$ and $\mathrm{Rz}$ ) when milling $\mathrm{X} 12 \mathrm{M}$ steel was experimented with and discussed. The results will guide the adjustment of the value of cutting parameters during the machining process to ensure that surface roughness is of small value.

\section{REFERENCES}

[1]. D. D. Trung, Influence of Cutting Parameters on Surface Roughness during Milling AISI 1045 Steel, Tribology in Industry, Vol. 42, No. 4, 2020, pp. 658-665.

[2]. Hasan Gökkaya, The Effects of Machining Parameters on Cutting Forces, Surface Roughness, Built-Up Edge (BUE) and Built-Up Layer (BUL) During Machining AA2014 (T4) Alloy, Strojniški vestnik - Journal of Mechanical Engineering, Vol. 56, 2010, pp. 584-593.

[3]. Muhammmad Yasir, Turnad Lenggo Ginta, Bambang Ariwahjoedi, Adam Umar Alkali, Mohd Danish, Effect of cutting spedd and feed rate on surface roughness of AISI 316LSS using end-milling, ARPN Journal of Engineering and
Applied Sciences, Vol. 11, No. 4, 2016, pp. 2496-2500.

[4]. Luis Wilfredo Hernández-González, Roberto Pérez-Rodríguez, Ana María Quesada-Estrada, Luminita Dumitrescu, Effects of cutting parameters on surface roughness and hardness in milling of AISI 304 steel, DYNA, Vol. 85, No. 205, 2018, pp. 57-63.

[5]. Huu-That Nguyen and Quang-Cherng Hsu, Surface Roughness Analysis in the Hard Milling of JIS SKD61 Alloy Steel, Applied Sciences, Vol. 6, No. 172, 2016, doi:10.3390/app6060172

[6]. B. N. Pathak, K. L. Sahoo, and Madhawanand Mishra, Effect of Machining Parameters on Cutting Forces and Surface Roughness in Al-(1-

2) Fe-1V-1Si Alloys, Materials and Manufacturing Processes, No. 28, 2013, pp. 463-469.

[7]. Erol Kilickap, Ahmet Yardimeden, Yahya $\mathrm{H}$, sman Çelik, Mathematical Modelling and Optimization of Cutting Force, Tool Wear and Surface Roughness by Using Artificial Neural Network and Response Surface Methodology in Milling of Ti-6242S, Applied Sciences, Vol. 7, No. 1064, 2017, doi:10.3390/app7101064

[8]. Okokpujie Imhade P., Okonkwo Ugochukwu C., Effects of Cutting Parameters on Surface Roughness during End Milling of Aluminium under Minimum Quantity Lubrication (MQL), International Journal of Science and Research, Vol. 4, No. 5, 2013, pp. 2937-2943.

[9]. Nguyễn Thanh Bình, Nguyễn Huy Ninh, Hoàng Tiến Dũng, Investigating the effect of cutting mode on surface roughness when milling on 5-axis UCP600 machine, Journal of Science and Technology, Vol. 53, No. 5,2015, pp. 671-678.

[10]. Phạm Thị Hoa, Đoàn Thị Hương, Nguyễn Quang Việt, Bành Tiến Long, Nguyễn Đức Toàn, Study the effects of cutting parameters on chip shrinkage and surface roughness when machining aluminum alloy A6061, 5th National 
Conference of Science and Technology on Mechanics, 2018. 11Angela Dean and Daniel Voss, Design and Analysis of Experiments, Springer, 1999.

[11]. Raymond H. Myers, Douglas C. Montgomery, Christine M. Anderson-Cook, Response Surface Methodology: Process and Product Optimization Using Designed Experiments, John Wiley \& Sons, Inc., 3rd Edition, 2009.

\section{Cite this article as :}

Do Thi Kim Lien, Nguyen Dinh Man, Phung Tran Dinh, "Investigate the Effect of Cutting Parameters on Surface Roughness When Milling X12m Steel", International Journal of Scientific Research in Science, Engineering and Technology (IJSRSET), Online ISSN : 2394-4099, Print ISSN : 2395-1990, Volume 8 Issue 2, pp. 258-263, March-April 2021. Available at doi : https://doi.org/10.32628/IJSRSET218255

Journal URL : https://ijsrset.com/IJSRSET218255 